\title{
Canadian Challenges in IMPLementing The KYoto PRotocol: A CAUSE FOR HARMONIZATION
}

\author{
Elisabeth DeMarco, Robert Routliffe \\ AND HEATHER LANDYMORE"
}

On 17 December 2002. Canada ratified the Kyoto Protocol to the United Nations Framework Convention on Climate Change (Kyoto Protocol), raking on binding targets to reduce Canadian emissions of greenhouse gases (GHGs). Canada's ratification decision and the proposed domessic emissions irading system forming part of Canada's Kyolo implementation plan continue to be the source of considerable disagreement and conflict between the provinces and the federal government regarding: the practical challenges associated with multiple Canadian jurisdictions implementing emissions trading systems: the current status and legal issues associated with covenants benveen indusiry and government(s) to enforce GHG reduction targets: the legal jurisdiction over domestic emissions trading system(s); and the impact on interprovincial and international trade. Each of these issues is examined in the unigue Canadian legal context. The authors conclude that many of the most significant challenges may be mitigated through harmonization and coordination by federal and provincial governments in a manner that allows for local concerns to be addressed without fragmenting the Canadian emissions markets.
Le 17 decembre 2002, le Canada a ratifié le Protocole de Kyolo de la Convention-cadre des Nations Unies sur le changement climatique (Protocole de Kyoto), etablissant des cibles obligatoires de reduction des émissions de gaz à effet de serre. La décision du Canada de ratifier le Protocole et le système d'échange de droits d'émissions qui s'inscril dans le plan de mise en auvre suggéré demeurent une importante source de mésentente el de conflit entre les provinces et le gouvernement fedéral en ce qui concerne les problemes pratigutes découlant des muliples juridictions canadiennes en matiere de systèmes d'echange de droits d'ëmissions. I'état actuel et les enjeux juridiques ayant trait aux garanties entre l'industrie et le ou les gouvernements relativement $\dot{a}$ l'application de ces cibles de réduction. II y a aussi la quession de la compésence légale en matière de systèmes d'échange de droits d'emission et l'incidence sur le commerce international et interprovincial. Chacume de ces questions est examinee dans le contexte juridique canadien particulier. Les auteurs en arrivent à la conclusion quiun grand nombre des problemes les plus importants peut ètre mitige par une harmonisation el coordination des gowvernements feddral et provinciaux de manière à pouvoir régler les préoccupations locales sans fragmenter les marchés des émissions canadiens.

\section{TABLE OF CONTENTS}

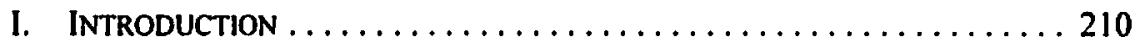

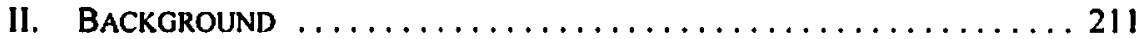

A. HIGHLIGHTS OF THE PROPOSED DOMESTIC

EMISSIONS TRADING SYSTEM $\ldots \ldots \ldots \ldots \ldots \ldots \ldots \ldots \ldots \ldots \ldots \ldots \ldots \ldots$

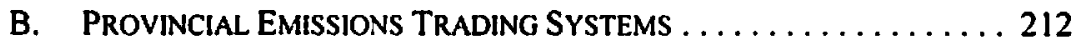

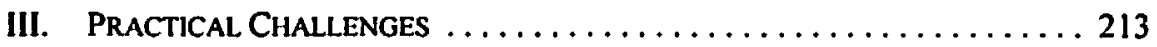

A. UNCERTAINTY AND INCONSISTENCY IN

REQUIRED EMISSION REDUCTIONS ................. 214

Elisabeth (Lisa) DeMarco is a partner of Macleod Dixon LLP and is based in Toronto, Ontario. Robert Routlifte is Global Manager, DuPont GHG Trading, based at Dupont Canada Inc. in Mississauga, Ontario. Heather Landymore is a Toronto associate with Macleod Dixon L..P. The authors gratefully acknowledge the research assistance provided by Nicola Covelli in Part IV.B.i of this article. Please note that views expressed are those of the authors and are not meant to $\mathrm{reflect}$ the thoughts or attitudes of either Macleod Dixon LLP, its clients, or Dupont Canada Ine. 
B. UNCERTAIN REgULATORY TREATMENT OF EARLY

EMISSION REDUCTION ACtIVITIES ................. 215

C. MULTIPLE AND POTENTIALLY INCONSISTENT MONITORING,

MEASUREMENT AND REPORTING REQUIREMENTS $\ldots \ldots \ldots \ldots \ldots 216$

D. DifFERING SECTOR DEFINITIONS AND BOUNDARIES ......... 217

E. DifFERENCES IN THE TIMing AND CALCULATION OF

RATE BASED Allocation MEChanisms $\ldots \ldots \ldots \ldots \ldots \ldots 217$

F. UNCERTAINTY AND INCONSISTENCY IN

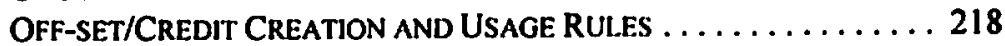

G. VARIABle EMISSION PRICE SIGNALS AND

Fluctuating EMISSION MARKet PRICES $\ldots \ldots \ldots \ldots \ldots \ldots 218$

H. POTENTIAL IMPACTS ON LONG-TERM

CONTRACTUAL ARRANGEMENTS $\ldots \ldots \ldots \ldots \ldots \ldots \ldots \ldots, 219$

I. VARIABLE ACCESS TO AND USE OF

INTERNATIONAL EMISSION MARKETS $\ldots \ldots \ldots \ldots \ldots \ldots \ldots 219$

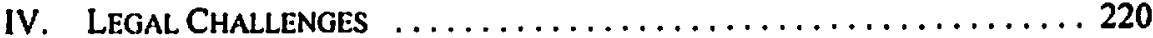

A. THE CURRENT STATUS AND LEGAL. ISSUES

Associated WITH SECTOR COVIENANTS $\ldots \ldots \ldots \ldots \ldots \ldots 221$

B. THE LEGAL AUTHORITY FOR EMISSIONS TRADING CONFERRED

BY THE CONSTITUTION OF CANADA ................ 226

C. LEGAL CHALLENGES RELATED TO INTERPROVINCIAL

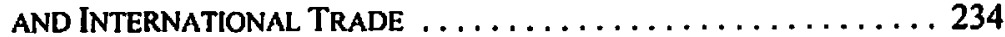

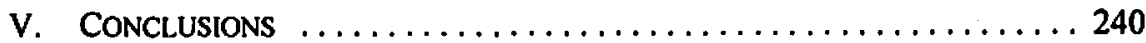

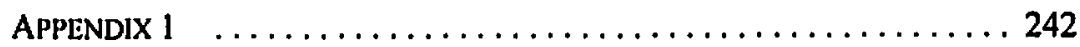

\section{INTRODUCTION}

On 17 December 2002, Canada ratified the Kyoto Protocol to the United Nations Framework Convention on Climate Change. 'The federal government's decision to ratify the Kyoto Protocol and the proposed domestic emission trading system included in Canada's proposed implementation plan continue to be the source of disagreement and conflict among Canadian governments regarding: (i) the practical challenges associated with multiple Canadian jurisdictions implementing emissions trading systems; (ii) sector covenants between industry and government(s) to enforce greenhouse gas (GHG) emission reduction targets; (iii) the legal jurisdiction over the subject matter of the proposed domestic emissions trading system(s); and (iv) the potential impacts on interprovincial and international trade.

The following analysis includes an examination of the above-mentioned practical and legal challenges that are likely to arise in the complex process of implementing the Kyoto Protocol and the proposed emissions trading system(s) in Canada. In order to facilitate this analysis, this examination is organized into three parts:

1. Background: This section sets out a general description of the current status of the plan to implement the Kyoto Protocol and the proposed domestic emissions trading system. 
2. Practical Challenges: This section includes an identification of the primary practical challenges that regulated large industrial emitters and regulators are likely to face as a result of the proposed domestic emissions trading system(s).

3. Legal Challenges: The final section provides an examination of the legal issues related to the use of sector covenants to enforce industry GHG emission reduction targets and the untested constitutional jurisdiction over emissions reductions and trading systems and interprovincial and international trade.

\section{BACKGROUND}

On 21 November 2002, the Government of Canada released its Climate Change Plan for Canada, ${ }^{2}$ which has become the central plan for implementing the Kyoto Protocol in Canada following Canadian ratification on 17 December 2002. The Implementation Plan includes a combination of current, proposed and future actions directed at seven main sectors of the Canadian economy in order to reduce GHG emissions and address the approximately 280 million metric tonnes (MT) of carbon dioxide equivalent $\left(\mathrm{CO}_{2} \mathrm{e}\right)$ by which Canada must reduce its output to meet its commitments under the Kyoto Protocol. The central features of the Implementation Plan include:

- the establishment of a domestic emissions trading system targeting the belowmentioned large industrial emitters (LIEs);

- the purchase of international emission reductions;

- maximizing emissions reduced by forestry and agricultural sinks;

- targeted regulatory measures directed primarily at the transportation, municipal, housing and building sectors;

- $\quad$ emission reduction objectives for individual Canadians;

- establishment of incentives for renewable energy, small and medium enterprise energy efficiency, clean fossil fuel and $\mathrm{CO}_{2}$ capture and sequestration infrastructure; and

a partnership fund to share costs of emission reductions with provincial and municipal governments.

\section{A. Highligits of the Proposed Domestic Emissions Trading SyStem}

The proposed emissions trading system will take the form of a hybrid emissions trading system ${ }^{3}$ requiring a total of nearly $100 \mathrm{MT}$ of $\mathrm{CO}_{2}$ emission reductions from stipulated large industrial emitters and allowing those emitters to use domestic emission offsets and international emission reductions to meet those commitments. Currently, the sectors that will be covered in the mandatory domestic emissions trading system include: thermal electricity generation (coal, oil and gas); oil and gas (upstream extraction, oil and gas pipelines, gas

2 Online:Government of Canada, Climate Change, <mww.climatechange.gc.ca/plan_for_canada/index. html> [Implementation Plan].

A hybrid emissions trading system is a combination of a closed "cap and trade" system, where emission permits or allowances are allocated to capped emitters and an open "credit" trading system, where credits or offsets are created by entities that are able to take action to reduce their emissions relative to their emission baseline. 
utilities and petroleum refining); mining; pulp and paper production; chemical production (including fertilizers); iron and steel production; smelting and refining; cement and lime production; and glass and glass container production.

The industry sector-based emission reduction commitments will be founded on sector covenants with the federal government that are backed by regulatory or financial measures. The federal government, through Natural Resources Canada, is currently in the process of negotiating sector-wide emission intensity factors and is scheduled to release a model sector covenant for negotiation purposes in the summer of 2003. Within targeted sectors, each facility will receive an allocation of allowances on the basis of its sector's emissions intensity factor, projected output and growth. Capped facilities will also have access to certain approved domestic offsets (currently proposed to come from agricultural and forestry sinks and possibly from landfill gas emission reductions) $)^{5}$ and international emission reductions (largely resulting from project-based emission credits arising out of the Clean Development and Joint Implementation mechanisms under the Kyoto Protocol) to meet their emission reduction requirements.

In response to industry concerns about international competitiveness and in particular about competition with U.S. market participants, the federal government has also committed to limiting both the quantity and price of emission reductions for certain capped industrial sectors. Specifically, the government has indicated that it will ensure that Canadian companies will not have to pay more than $\$ 15(\mathrm{Cdn}) /$ tonne $\mathrm{CO}_{2}$ to meet their emission reduction targets. ${ }^{6}$ If the price of $\mathrm{CO}_{2}$ allowances and offsets exceeds this limit, the government is likely to make up the shortfall through international credit purchases. The government has also committed that the oil and gas sector emission intensity target will be set at a level that will require no more than a 15 percent reduction from business-as-usual emission levels in 2010. Recent Environment Canada statements have contributed to considerable industry uncertainty regarding the conditions, nature and extent of the govermment's pricing and quantity guarantee.?

It is noteworthy that a large number of unresolved market design parameters pertaining to the proposed domestic emission trading system must be determined and finalized before the scheduled implementation in 2005-2006.

\section{B. Provincial Emissions Trading Systems}

Several provinces, including Ontario and Alberta, have also developed emissions trading policy initiatives. In October 2001 , Ontario implemented a regulated system of emissions trading applicable to $\mathrm{NO}_{\mathrm{x}}$ and $\mathrm{SO}_{2}$ emissions from the electricity sector. ${ }^{8}$ The Emissions

- Environment Canada, Climate Change Bureau.

3 Environment Canada. Designing a Greenhouse Gas Ofset System for Canada (Ottawa: Climate Change Bureau, 2003), online: <www.climatechange.gc.ca/english/publications/offsets/ cover.html>. Government commitments enunciated in an open letter from Minister of Natural Resources Herb Dhaliwal, December 2002.

Most recently, during the negotiation of the sector emission intensity targets, Assistant Deputy Minister Howard Brown indicated to certain large industries that the \$ I S/tonne pricing guarantec may only apply if a company is "prudent" in its greenhouse gas mitigation strategy.

Emissions Trading, O. Reg. 397/01, as amended [Emissions Trading Regulation]. 
Trading Regulation provides for a hybrid "cap, credit and trade" system that allows capped emitters to use: (i) allocated Ontario allowances; (ii) U.S. $\mathrm{NO}_{\mathrm{x}}$ and $\mathrm{SO}_{2}$ allowances; and (iii) emission reduction credits that are created in accordance with defined "standard methods" to comply with absolute annual emission constraints. The Ontario government plans to extend the Emissions Trading Regulation to eight other industrial sectors' in 2004 and possibly to GHGs at a later date. ${ }^{10}$

Alberta recently introduced Bill 37, The Climate Change and Emissions Management $A c t$," which received royal assent on 4 December 2003. Bill 37 sets out an Alberta GHG emission reduction target of 50 percent reduction in GHG intensity (GHG emissions per unit GDP) by 2020 and provides for a system of emissions trading to achieve same. Bill 37 also provides for a hybrid system of emissions trading and contemplates the negotiation of sectoral covenants with industry that will be backed by regulatory or financial measures in order to achieve the required emission reduction commitments. There is significant regulation-making authority included in Bill 37 that will allow Alberta to regulate the use of offsets for compliance, carbons sinks (soils, forests) as a provincial property right, mandatory GHG reporting requirements and a climate change fund. It also provides for the creation of an offence, administrative monetary penalties and director and officer liability to address non-compliance.

A number of other provinces, including British Columbia, Manitoba, Nova Scotia, Newfoundland, New Brunswick, Quebec and the Yukon Territory also have legislation which allows for emissions trading systems to be developed in those jurisdictions. The precise nature of the legislative authority for emissions trading in each of these jurisdictions is set out in Appendix 1. In total, there are currently three distinct Canadian emissions trading systems in various stages of development and the potential for a further seven distinct cmissions trading systems authorized by legislation. The existence of at least ten potential Canadian emissions trading systems presents a significant number of practical challenges for both regulators attempting to administer such systems and regulated entities attempting to comply multiple and varying emission reduction commitments and emission market rules. A more detailed examination of these practical challenges follows.

\section{ili. Practical, Chal,jenges}

The existence of multiple and varying Canadian emission reduction requirements and emissions trading systems that are administered by differing Canadian jurisdictions presents a number of practical challenges. The following practical challenges have been elucidated primarily from the perspective of a regulated entity, but include certain challenges that are likely to be encountered by regulators. The practical challenges associated with the implementation of numerous emissions trading systems to achieve emission reductions within

- Ontario, Ministry of the Environment, Discussion Paper on Onfario 's Clean dir Plan for Indesily: Developing $\mathrm{NO}_{\mathrm{r}}$ and $\mathrm{SO}_{2}$ Emission Limits (Toronto: Ministry of the Environnent, 2002), online: Ontario Ministry of the Environment <www.ent.gov.on.ca/envision/air/capi/discussion pdi> [Discussion Paper on Ontario's Clean Air Plan].

(1) As indicated in Ontario Ministry of Environment Press Release, 24 January 2001. online: Ontario Ministry of the Environment <umw.ene. gov.on.ca/envision/news/10240mb.htm>

" 3rd Sess., 25th Leg. (assented to 4 December 2003. not yet proclaimed as of publication), also found at R.S.A. 2000, c. 16.7 [Bill 37]. 
Canada include: (i) uncertainty and inconsistency in required emission reductions; (ii) uncertain and differing regulatory treatment of early emission reduction activities; (iii) multiple and potentially inconsistent reporting requirements; (iv) differing sector definitions and boundaries; ( $v$ ) differences in the timing and calculations of rate-based allocation mechanisms; (vi) uncertainty and inconsistency in offset/credit creation and usage rules; (vii) variable emission price signals and fluctuating emissions market prices; (viii) potential impacts on long-term contractual arrangements; and (ix) variable access to and use of international emission markets. Each of these practical challenges is considered below.

\section{A. UnCERTAINTY AND INCONSISTENCY IN REQUIRED EMISSION REDUCTIONS}

Currently Parliament and the Alberta government are pursuing GHG emission reduction and trading policy initiatives. These proposed parallel emissions reduction and trading initiatives are likely to result in inconsistent emission reduction requirements and emission market rules for regulated emitters that are subject to the requirements of both jurisdictions. Specifically, the Implementation Plan and Bill 37 differ in all of the following: the absolute magnitude of emission reductions required; the metric for measuring emission reductions; and the timing by which such reductions must be made.

Although the absolute emission reductions required by the federal government for any particular company and/or industry sector have yet to be finalized, the federal government is seeking to obtain from industry an absolute reduction in GHG in the range of 25 to 32 percent from business-as-usual emissions in the year 2010, as set out in Figure $1 .^{12}$ The Implementation Plan further indicates that the government is looking to capped, large industrial emitters to make reductions in the range of $100 \mathrm{MT}$ of $\mathrm{CO}_{2}$ equivalent by the year $2010 .^{13}$ In contrast, s. 3(1) of Bill 37 mandates a provincial emission reduction target of a 50 percent decrease in GHG emission intensity from 1990 levels by the year $2020 .^{14}$ It is estimated that this translates to an absolute emission reduction of $60 \mathrm{MT} \mathrm{CO}_{2}$ e from businessas-usual projections by the year $2020 .^{\text {is }}$

Such different emission reduction targets are probably subject to many of the individual regulated entities that are likely to be covered by both the federal and Alberta initiatives to different real emission reduction requirements.

In addition, the relevant unit of measurement employed by each of these jurisdictions to determine if compliance is achieved is also different. Specifically, the Alberta target is measured in units of GHG emissions relative to Gross Domestic Product. ${ }^{16}$ In contrast, the federal government is seeking to achieve GHG emissions reductions in the range of 280 MT."

Implementation Plan, supra note 2.

Ibid. at 4.

Bill 37, supra note 11.

Government of Alberta, Albertans and Climate Change: Taking Action (Edmonton: Government of Alberta, 2002) at 2 [Climate Change: Taking Action].

Supra note 11 , s. 3(1).

Implementation Plan, supra note 2 at 12 
Thirdly, the federal government intends to achieve its targeted GHG reductions by 20082012 in accordance with the first commitment period stipulated in the Kyoto Protocol. In contrast, Alberta intends to meet its target by 2020 .

Moreover, the Alberta and federal emission reduction targets and systems may differ in the number and scope of contaminants that are covered. Specifically, the Alberta Environment External Reference Group is currently considering a major feasibility study ${ }^{18}$ looking at mandatory emission reduction targets for all of: oxides and nitrogen $\left(\mathrm{NO}_{\mathrm{x}}\right)$; sulfur dioxide $\left(\mathrm{SO}_{2}\right)$; mercury $(\mathrm{Hg})$; and all GHGs (including $\mathrm{CO}_{2}, \mathrm{CH}_{4}, \mathrm{~N}_{2} \mathrm{O}, \mathrm{PFCs}, \mathrm{HFCs}$ and $\mathrm{SF}_{6}$ ). The federal /mplementation Plan provides for emission reductions and trading of only GHGs. In further contrast, the current Ontario emission reduction targets and trading system applies only to $\mathrm{NO}_{x}$ and $\mathrm{SO}_{2} .{ }^{19}$ The differing scope and application of each of the federal, Alberta and Ontario emissions trading systems is likely to lead to confusing and potentially conflicting emission compliance decisions for regulated entities that are subject to more than one of the above-mentioned regulatory instruments.

The multiple and varying emission reduction targets and trading systems also present a number of practical challenges for environmental regulators that are charged with the task of ensuring compliance with a particular target and trading system. Contrasting and conflicting paradigms are likely to give rise to jurisdictional battles that may delay the achievement of particular emission reduction commitments and give rise to public concern and calls for government accountability. In practice, this result may mean that Canada does not meet its Kyoto commitments within the first commitment period of 2008-2012, and Alberta may have difficulty in ensuring that its multiple emission reduction requirements are met in light of the possible paramountcy of the federal GHG targets and trading system. ${ }^{20}$ Such implications lead to even greater uncertainty on the part of the regulated large industrial emitter, which may be subject to further required emission reductions in order to ensure that emission reduction commitments are met.

\section{B. UNCERTAIN REGULATORY TREATMENT OF EARLY EMISSION REDUCTION ACTIVITIES}

Multiple emission trading systems and emission reduction targets may also have the unintended effect of dissuading regulated large industrial emitters from implementing early emission reduction activities as a result of the uncertain and potentially conflicting treatment of such activities under numerous Canadian emissions trading systems. In particular, regulated emitters are likely to be reticent to move forward with emission reduction activities on the basis of assurances and agreement from one level of government, without obtaining similar assurances from any and all other jurisdictions intending to implement emission

Alberta, Ministry of the Environment, Major Feasibility Study: Preliminary Analysis and Discussion Document (Alberta: Ministry of the Environment, May 2003), online: Alberta Environment Air Emissions Trading Project <www3.gov.ab.ca/env/air/emmisions_trading/studies.html\#studics> [Major Feasibility Situdy].

19 Supra note 8.

20) The doctrine of federal paramountcy provides that where there are inconsistent or conflicting federal or provincial laws, the federal law prevails. See Neil Finkelstein, Laskin's Canadian Constitutional Law, 5th ed. (Toronto: Carswell, 1986) at 262-91 and Peter W. Hogg. Constitutional Lan' of Canada. 3rd ed. (Scarborough: Carswell, 1992) at 418-19. 
reduction requirements. Given that regulators generally look to historical emissions in order to determine feasible emission reduction requirements, a regulated entity may be incented to delay early reduction activities until a reasonable level of certainty regarding each jurisdiction's emission reduction requirements is obtained. The resulting potential delay in the implementation and realization of early emission reductions is contrary to the environmental policy goals of each regulator involved.

\section{Multiple and Potential.ly InConsistent Monitoring, MEASUREMENT AND REPORTING REQUIREMENTS}

There are currently a number of regulatory instruments that require the monitoring and reporting of criteria air contaminants and GHGs to various regulatory authorities. The National Pollutant Release Inventory (NPRI), which is administered by Environment Canada under s. 45(1) of the Canadian Environmental Protection Act 1999, ${ }^{21}$ currently requires reporting of a number of criteria air contaminants (CACs) ${ }^{22}$ and, starting in 2005 , will require reporting on $2004 \mathrm{GHG}$ emissions. ${ }^{23}$

The Ontario government currently requires reporting of CAC and GHG emissions pursuant to its Airborne Containment Discharge Monitoring and Reporting Regulation, ${ }^{24}$ and further reporting on CAC emissions from the electricity sector pursuant to the Emissions Trading Regulation. ${ }^{25}$ Alberta will also require mandatory reporting of GHG emissions ${ }^{26}$ and currently requires limited CAC reporting through the NPRI to support Alberta Environment approvals under the Environmental Protection and Enhancement Act. ${ }^{27}$

The simultaneous operation of each of these regulated reporting requirements results in multiple and potentially inconsistent measurement, monitoring and reporting requirements for regulated entities. Specifically, differing thresholds, exemptions, substances, timing deadlines and measurement equipment requirements (particularly between Ontario and federal requirements) lead to additional regulatory and administrative burden and confusion for both governments and industry. Although a number of initiatives are underway to harmonize and simplify the varying reporting requirements of multiple Canadian jurisdictions, ${ }^{28}$ the situation is likely to be exacerbated when both the Alberta and National Pollutant Release Inventory Greenhouse Gas reporting requirements come into effect in the next few years.

S.C. 1999 , c. $33[C E P A]$.

Including $\mathrm{NO}_{2}, \mathrm{SO}_{2}$, VOCs, Particulate Matter and $\mathrm{CO}$ as per Part 4 of Environment Canada, National Pollutant Release Inventory Substance Lisf (Ottawa: Environment Canada, 2002), online: Environment Canada <wwww.ec.ge.ca/pdb/npri/documents/2002substancelits_e.pdß).

Environment Canada, Environment Canada's Response to Recommendations of the Second Report of the NPRI Multi-Siakeholder Workgroup on Substances (2001-2002) (Ottawa: Environment Canada, 2002) at 1.

O. Reg. $127 / 01$.

Supra note 8.

Bill 37, supra note 11 , ss. 6 and 7.

R.S.A. 2000, c. E-12.

A three year pilot project was established by Environment Canada and the Ontario Ministry of the Environment in attempt to harmonize and streamline reporting requirements. Sec Environment Canada, A Comprehensive Review of the Differences Benveen the NPRI and O. Reg. 127/01 (Ottawa: Environment Canada, 2002) at 3. 


\section{Differing SeCtor Definitions ANd Boundaries}

The federal Implementation Plan, Bill 37 and the Ontario Clean Air Plan for Industry ${ }^{29}$ all contemplate the use of sector-wide emission intensity factors and sectoral covenants between industry and government(s) to enforce emission reduction targets upon which emission trading systems will operate. There is currently, however, little consistency and clear direction regarding how each specific industry sector will be defined for air emission regulatory purposes. As a result, it is possible for a specific regulated facility to be part of one industry sector for federal purposes and a different sector in certain provinces. In this event, an entity may be subject to differing GHG emission reduction requirements and/or emission intensity factors.

Sector boundaries may be particularly problematic where a facility's GHG emissions result from both industrial processes and on-site energy generation or "co-generation." In this situation, it is unclear as to whether the GHG emissions from the facility and the required emission reduction(s) will be treated as part of a single industrial sector, such as steel, or divided among sectors, such as steel and electrical power generation.

A very broad definition of certain sectors is likely to lead to a sector composed of entities with widely varying emission rates and production output parameters. The net result may be windfall financial gains and losses for disparate members of the sector and a politically unfeasible transfer of wealth. In contrast, a very narrow sector definition could have the effect of essentially imposing command and control emission reduction requirements on a small number of facilities, thereby negating the force and efficiency of a market mechanism to achieve emission reductions.

\section{E. Differences in the Timing and Calculation of RATE BASED AlLoCATION MEChANISMS}

Emission rate based allocation mechanisms allow for the distribution of emission rights generally on the basis of past or relative emission rates. In this manner, emission allowances are generally allocated on the basis of past production cycles and output data. In the event that the past production cycle data is not reflective of economic conditions in the compliance year (which could either be characterized by economic growth or contraction), there is a regulatory lag that must be addressed by the regulated entity through appropriate emissions risk mitigation strategies.

Although the allocation mechanism in the Ontario emissions trading system is currently not based on rates but rather on absolute production data, the allocation mechanism is subject to a two-year lag, or in other words companies receive 2004 allowance allocations on the basis of their 2002 electricity output.

It is unclear whether or not the federal and Alberta emissions trading systems will also provide for a two-year regulatory lag. In the event that they do not, regulated entities will be 
subject to additional complexity and administrative burdens as a result of having to mitigate emission risks associated with multiple and varying allocation rules.

\section{F. UNCERTAINTY AND INCONSISTENCY IN OFF-SET/CREDIT Creation and Usage Rul.fS}

Generally, regulators allow for emission offsets/credits to be created from entities that do not have mandated emission reduction requirements in order to encourage innovation and maximize potential emission reductions in the jurisdiction. To date, however, jurisdictions such as Ontario, Alberta and the federal government that are implementing hybrid emission trading systems have stipulated the specific types of activities that may result in the creation of eligible offsets/credits.

The Ontario emission trading regulation provides for credit creation through fuel switching and the installation of low $\mathrm{NO}_{x}$ burners. In addition, it allows for set-aside allowances to be created from renewable energy and conservation projects. ${ }^{30}$ it currently does not allow for credits to be created from landfill gas operations. In contrast, the federal Implementation Plan contemplates eligible offsets from carbon sequestration through biological and geological sinks and potential landfill gas operations. Bill 37 contemplates a further type of offsets created through the storage of GHGs in a "constructed facility." These differences in offset creation rules may be particularly problematic if they are accompanied by differing offset usage rules in each of these jurisdictions.

Ontario is the only jurisdiction that has promulgated specific rules regarding the use of credits. ${ }^{32}$ The rules regarding the use of credits are very different and far more restrictive than the rules regarding the use of government-allocated allowances. As a result, this has greatly impeded the fungibility of credits and allowances and thereby the liquidity of the Ontario emissions market. Consequently, government success in meeting its environmental and economic objectives from emissions trading has been limited.

\section{G. Variable Emission Price Signats and Fluctuating EMission Market Prices}

In response to a number of industry concerns regarding the ultimate cost and quantity of emission reductions required by a variety of jurisdictions, the federal government has indicated that it will provide both emissions price and emission reduction quantity guarantees for the oil and gas sector. The Alberta govermment has also committed to provide regulated entities with an emissions price guarantee.

The federal government has committed to a carbon emission reduction price cap of \$15/ tonne $\mathrm{CO}_{2} \mathrm{e}$, and a guarantee that the oil and gas sector will be required to reduce GHG 
emissions by no more than 15 percent from projected 2010 emission levels. ${ }^{33}$ In contrast, the Alberta government has indicated that it is likely to provide a price guarantee of $\$ 10 /$ tonne $\mathrm{CO}_{2} \mathrm{e} .{ }^{34}$ The differing price caps are likely to lead to a further fragmentation of the Canadian GHG emissions market into several sub-markets.

Specifically, differing price caps are likely to lead to an individual Alberta market price for $\mathrm{CO}_{2} \mathrm{e}$ and a different Canadian market price for $\mathrm{CO}_{2} \mathrm{e}$, with foreseeable and largely negative consequences. It is very likely that any Alberta emission reductions that cost more than \$10/tonne will not occur. If Alberta allowances can be used in the Canadian system, emitters in Alberta will be incented to purchase $\$ 10$ allowances in the Alberta emissions market and sell them into the $\$ 15$ cap Canadian emissions market. As such, the possibilities for arbitrage appear to be extensive. If pricing and market is necessary to ensure that companies are not faced with staggering emission control costs, Canadian jurisdictions should attempt to harmonize such guarantees to ensure that markets are not artificially fragmented by multiple interferences in market pricing.

\section{H. Potential. Impacts on Long-Term Contractlal. ArRangements}

A very significant number of large industrial emitters that will be subject to emissions constraints imposed by one or several Canadian jurisdictions are parties to long-term contracts for the purchase and sale of industry-specific goods or services that may be affected by the proposed emission reduction and trading requirements. Given that a number of jurisdictions plan to implement the emission reduction obligations through voluntary agreements (also called sector covenants) with a regulatory and/or financial backstop, it is uncertain how the compliance costs associated with the "requirements" set out in a voluntary agreement will be treated under such long-term contractual arrangements. In particular, longterm purchase and supply contracts generally make provision for the pass through of costs associated with a change of law and specify which party bears the financial risk of such changes. Given the potentially voluntary nature of sector covenants, it is uncertain whether entering into a sector covenant will constitute a law, giving rise to a change in law under long-term contracts that address treatment of the costs arising from a change of law.

\section{VARIABLFS ACCESS TO AND USE OF INTERNATIONAL EMISSION MARKETS}

From the regulated entity's perspective, access to and use of international emissions markets and commodities provides additional opportunities to hedge and mitigate emissions regulatory risk. If regulated large industrial emitters are provided access to, and permitted use of, Kyoto emission commodities, including an assigned amount of emission reduction units (AAUs), certified emission reductions (CERs), emission reduction units (ERUs) and carbon sink based removal units (RMUs), they will have a greater opportunity to mitigate their emissions risk. Specifically, they may develop broader trading strategies, make better use of financial instruments related to emissions reduction, and have the flexibility associated

$" \quad$ Natural Resources Canada. "Large Final Emilters Policy liramework" at 5 (Powerpoint presentalion lo Working Group of the International Emissions Trading Association. Calgary. April 20(1), [unpublished].

4 Environment Minister. Lorne Taylor used differing pricing guarantees that are likely to provide very different emission price signals in Alberta versus nationally in Canada. 
with trade in emission commodities resulting from other Kyoto signatory countries. On the other hand, this flexibility comes with greater exposure to price volatility in the much larger global emissions market.

From the Canadian regulators' perspective, the federal government is loosely obliged to ensure that a significant amount of Canada's emissions reductions are made domestically under the supplementarity requirements of the Kyoto Protocol..$^{35}$ Certainly, political considerations as well as the local benefits that result from reduced combustion of fossil fuels will encourage regulation that favours domestic emission reductions. Provincial regulators may also have the conflicting objectives of ensuring that: (i) provincially governed entities may access the lowest cost emission reductions for compliance with any mandated emission reduction requirement; and (ii) the province takes action that results in local benefits of emission reductions in the province. As a result, regulators may be incented to provide certain limits on the access to, and use of, international emission commodities in order to minimize risk exposure and maximize potential domestic reductions.

In instances where certain Canadian jurisdictions provide for access to the international emission markets and others do not, this will significantly increase the potential for emissions arbitrage and thereby limit the intended environmental benefits of emissions trading. Therefore, coordination and harmonization among Canadian governments regarding the access to international emission markets and use of international emission commodities is required.

In conclusion on this point, in the event that any or all of the above-mentioned practical challenges remain unresolved through the coordination and harmonization of federal and provincial governments, there is a significant likelihood that a legal challenge will arise relating to the multiple and varying emission reduction and trading requirements.

\section{Legal Challenges}

In the event that practical challenges associated with multiple and varying Canadian emission reduction and trading requirements give rise to unresolved conflicts between federal and provincial governments and/or government(s) and industry, there are three main aspects of the proposed emissions trading policy initiatives that are most likely to be the subject of legal challenge. They are: first, the current status and legal issues associated with sectoral covenants between industry and government(s) in order to implement and enforce mandated emission reductions; second, the legal authority for emissions trading that is conferred upon the government in question by the Constitution Act, $1867 ;{ }^{36}$ and third, the effects of the proposed emissions reductions and trading system on interprovincial and international trade. A consideration of each follows. 


\section{A. The Current Status and Legal Issues Associated WITH Sector Covenants}

\section{BACKGROUND}

Generally, sector covenants are voluntary agreements between at least two parties, one of which is a governmental authority, and the other a representative of an industrial sector of the economy. Sector covenants generally include some form of an agreement with respect to an industry sector's targeted environmental performance and a government commitment regarding its expectations and requirements of the industry sector in relation to environmental performance. ${ }^{37}$ This type of agreement was first coined an "environmental covenant" in the Netherlands' National Environmental Policy Plan, ${ }^{38}$ introduced in the early 1990 s. These types of environmental agreements between government and industry appear to be synonymously referred to as "voluntary agreements," "sector(al) or environmental covenants," and "cooperative agreements" throughout different jurisdictions in Europe and North America. The authors use each of the terms interchangeably. ${ }^{39}$

Sector covenants may be either binding or non-binding, and may or may not be implemented under the aegis of legislation. Generally, they take three main forms: (i) nonlegislated, non-binding agreements, which include general environmental targets; (ii) nonlegislated agreements with specific environmental targets that purport to be binding; and (iii) legislated agreements with specific and binding environmental targets. ${ }^{40}$

An examination of: (i) the current status of sector covenants related to emission reductions and trading in key Canadian jurisdictions; and (ii) potential legal issues that are associated with the use of sector covenants to implement and enforce emission reduction obligations follows.

\section{The CurRent Status of Sector Covenants Related to EMISSION REDUCTIONS AND TRADING IN KEY CANADIAN JURISDICTIONS}

A number of federal and provincial regulators, including Alberta, Ontario and Quebec, are implementing environmental covenants between specific industrial facilities or sectors as an environmental regulatory and compliance tool. Each of the above-mentioned jurisdictions intends to use sector covenants to implement and enforce the emission reduction obligations that form the basis of their new or expanding emission reduction and trading systems.

In Alberta, s. 4 of Bill 37 provides the Alberta Minister of Environment with broad authority to enter into "agreements with representatives of different sectors of the Alberta

P. Glasbergen, "Partnership as a learning process" in P. Glasbergen, ed., Co-operative Environmental Governance: Public-Private Agreements as a Policy Sirategy (Netherlands: Kluwer, 1998) at 133. Netherlands, Ministry of Housing, Spatial Planning, and the Environment, National Environmental Policy Plan (VROM International, 1989), online: VROM International <www.vrom.nl/international>.

34 As they are currently termed in Ontario.

40. I. Sumikura, "Environmental Voluntary Agreements and the Rule of Law in England and Japan: Common Law Perspectives and Civil Law Perspectives Compared" (CAVA Working Paper no.2000/2/15, paper presented to the Fourth Workshop of the CAVA Network, Brussels, February $2000)$ at 5 . 
economy" ${ }^{\text {41 }}$ regarding: meeting emission targets; energy efficiency levels; maximum emission intensities; emission reduction time schedules; emission baselines; reporting requirements; emissions measurement, monitoring, reporting and verification; sectoral infrastructure; emission financing; technological changes; cooperation on technology; options to meet emission targets; compliance and enforcement with the agreement, including financial penalties; payment into a climate change fund; and other matters in the Minister's discretion.

In Quebec, the aluminum sector entered into a framework agreement for GHG emission reduction targets with the Government of Quebec in 2002.2 The agreement sets GHG emission reduction targets for the period ending December 2007, allows companies to use emissions trading for compliance, and includes provisions for monitoring, reporting and audits.

In Ontario, the Ministry of the Environment and the Automotive Parts Manufacturers' Association (APMA) have entered into a cooperative agreement targeting reduction of air emissions from the sector. ${ }^{\text {13 }}$ The APMA Agreement is intended to be binding, but is not enacted under specific legislation. Although the Ontario Environmental Protection Act provides that the Minister may "with the approval of the Lieutenant Governor in Council, enter into an agreement with any government or person relating to the protection or conservation of the natural environment," there is in Alberta's Bill 37, to enter into such agreements with representatives of different sectors of the economy. Section 2.7 of the APMA Agreement generally provides that if a facility is out of compliance with the agreement it will lose its privileges and status under the cooperative agreement. In addition, the APMA Agreement is intended to work in coordination with, not outside of, other Ontario environmental legislation. ${ }^{\text {ts }}$

Environment Canada has recently indicated that it intends to develop a climate change covenant system for three main large industrial sectors: electricity, oil and gas and mining and manufacturing. ${ }^{46}$ The covenants will have the following seven elements: (i) a 55 MT emission reduction target from 2010 projected levels; (ii) intensity-based emission reduction targets; (iii) access to domestic offsets; (iv) access to domestic and international trading; (v) access to domestic allowances at a maximum price of \$15/tonne; (vi) provisions to ensure no disadvantage for early movers; and (vii) provisions to address sectoral competitiveness. ${ }^{47}$

Bill 37, supra note 11 , s.4.

Quebec Ministre de I-Environment, Workshop on Negotiating Agreements between Governments and Industries, 17-18 March 2003 [Framework Agreement].

Cooperative Agreement: Automotive Parts Manufacturers' Association (AMPA), online: Ontario, Ministry of Environment <www.ene.gov.un.ca/envision/general//eadership/apma\%5Fagreement.htm> [APMA Agrcement].

R.S.O. 1990, c. E-19, s. $4(1)(j)$.

APMA Agreement, supra note 43. Subsection 2.7.1 provides that "Participation in this Pilot Project does not exclude any Facility from any and all applicable provincial, federal and municipal laws, regulations, policies and guidelines."

Paul Fauteux, Director General of the Climate Change Bureau of Environment Canada, "Emerging Fcderal Plans for Mecting the Kyoto Turgets" (Presentation to the Greenlıousc Gas Emission Reduction and Trading Workshop, Toronto, February 2003). See Ray Rivers \& Betty Rozendaal, "Greenhouse Gas Emission Reduction and Trading Workshop: Workshop Report," online: CleanAir Canada <www. cleanaircanada.org/upld_doc/cac_doc/CleanAir\%20Canada\%20GHG\%20Workshop\% 20Report\%20final.pds?.

lbid. 


\section{POTENTIAL LEGal ISSUES THAT ARE ASSOCIATED WITH THE USE OF SECTOR COVENANTS TO IMPLEMENT AND ENFORCE EMISSION REDUCTION OBLIGATIONS}

A significant number of legal issues arise in relation to the use of voluntary agreements to implement emission reduction requirements and enforce compliance, particularly when the agreement is not enacted under the authority of specific legislation, yet contains specific environmental targets and sanctions that are intended to be legally binding. These issues include: (i) the nature and force of environmental covenants under administrative law or the common law of contract; (ii) the legal status and accountability of each counter-party to an environmental covenant; and (iii) whether these environmental agreements are a legitimate exercise of executive power over a matter otherwise reserved for the legislature.

i. What is the Nature and Force of Environmental Covenants as Instruments Under Administrative Law or the Common Law of Contract?

Voluntary agreements are similar in many ways to contracts in that they are negotiated by at least two parties and the terms are generally reflective of those found in private contracts. However, given that one of the parties to the contract is a government body, these contracts may extend beyond the bounds of private law contracts and affect or constrain the use of traditional public law instruments. ${ }^{48}$ Therefore, the use of environmental covenants may result in a situation whereby a contractual mechanism is used to control the discretion otherwise exercised by governmental authorities.

The unique natuie of covenants may give rise to valid legal arguments to suggest that these voluntary agreements are more in the nature of an undertaking with an administrative body which, upon entering into the agreement, becomes functus officio on the matters set out therein.

It may also be argued that environmental covenants should be given the full force and effect of a contract at common law and afforded all rights and remedies associated therewith. This interpretation would be particularly strained in the absence of express legislation authorizing the specific government entity to enter into and bind the government in question.

In either case, it is possible that an unsuccessful sector covenant could be challenged on the grounds that the government fettered its discretion and/or improperly delegated its authority regarding the subject matter of the covenant. Such issues lead to a consideration of the unique counter-party risks associated with environmental covenants.

* R. Julich \& H. Falk, "The Integration of Voluntary Approaches into Existing Legal Systems" (CAVA Working Paper no.99/09/4), supra note 40 at 9 . See also Peter Borkey, Matthieu Glachant \& François Léveque, Voluntary Approaches for Environmental Policy: An Assessment (Paris: Organisation for Economic Co-operation and Development (OECD), 1999) at 10. 
ii. What is the Legal Status and Accountability of Each Counter-Party to an Environmental Covenant?

In a voluntary agreement to implement and enforce emission reduction requirements, there are unique counter-party risks that are not generally encountered in a private contract. As indicated above, the industry party will want heightened assurance of the government entity's express authority to enter into the agreement and bind the Crown. In addition, in an agreement of this nature, legal questions may arise regarding the ability of the government representative to bind future and successive governments. Moreover, in the event that the industry sector enters into covenants with more than one level of government, it will likely require consistency between the agreements and formal agreement among the governments regarding the ongoing validity, applicability and operability of the multiple environmental covenants.

The government entity also faces unique counter-party issues in the event that the covenant is with a representative of an industry sector, such as an industry association. In many instances, industry associations have not incorporated and do not have legal personhood. As a result, their ability to enter into contracts and bind their respective members may be very limited. Specifically, the government must ensure that the organization has been provided with proper legal authority from each member of the association in order to enter into the covenant and bind each member. In addition, the government is also likely to require assurance that the person negotiating and contracting on behalf of the association has all legal authority required to do so.

\section{iii. Are These Environmental Agreements a Legitimate Exercise of Executive Power Over a Matter Otherwise Reserved for the Legislature?}

When voluntary agreements contain sanctions, but are not introduced through, or in conjunction with, legislation, they essentially serve a purpose that is otherwise reserved for legislation or regulation. In the absence of an environmental covenant, it is likely that the regulator would be required to use a traditional regulatory instrument to achieve the same emission reductions and performance set out in the covenant. It is very possible that such action may be construed as the executive branch of government entering into a contract in relation to a matter, which should be subject to the checks and balances that are required of the legislative branch of government.

If an overreaching law does not empower the executive branch of government to enter into such agreements, it is very possible that the environmental contracts will not be legally binding. ${ }^{49}$ In addition to the issue of contractual validity, environmental covenants between the executive branch of government and industry may raise certain issues with respect to legitimacy and public accountability.

Such issues were encountered in the Netherlands, where the use of sector covenants first began as a form of informal non-binding co-operative agreement between industries and 
regulatory authorities that was based on a long history of cooperative regulation. In the Netherlands, the legal basis of the voluntary agreements or covenants was challenged in the courts, as environmental groups were concemed with their inability to influence these agreements. ${ }^{\text {so }}$ In the end, the courts ruled that voluntary agreements cannot contradict environmental legislation, but it is possible to use voluntary agreements to anticipate legislation that has yet to be formulated. Environmental covenants cannot, however, replace legislation."

The issues of both public accountability and state responsibility, in the context of environmental covenants, led the Netherlands to incorporate the covenants into legislation and thereby solidify their legal force and effect. As a result, the Dutch voluntary agreements are now part of the publicly available Netherlands ' National Environmental Policy Plan, ${ }^{52}$ which has been adopted by Parliament. ${ }^{33}$

Certain issues regarding environmental covenants also arise in the context of the Canadian Charter of Rights and Freedoms. ${ }^{54}$ Most modern constitutional states adhere to the principal of the "rule of law," the idea that the exercise of governmental authority is subject to legal control. In Canada, various legislative mechanisms exist to harness the free rein of government authority, such as the Charter and the legal protection provided by the associated body of administrative law.

Although environmental covenants may be functionally equivalent to legislation, they may escape the traditional limits on the exercise of government authority, given that the Charter applies primarily to the exercise of statute-based powers. ${ }^{35}$ Therefore environmental covenants, particularly those that are neither subject to public scrutiny and accountability nor entered into under legislation, may unduly interfere with the rule of law and the associated checks and balances provided by a federation. ${ }^{56}$ Further, the increased use of environmental covenants may affect a country's democratic balance by shifting power from the legislative branch to the executive branch of government. ${ }^{37}$

In summary, there are a plethora of practical and legal issues that governments and regulated entities need to be cognizant of when negotiating and entering into sector covenants. To the extent that regulated sectors are required to enter into covenants with more than one government, these issues will be compounded. As a result, coordination, simplification and harmonization are warranted in order to implement effective sector covenants to achieve GHG emission reductions and trading.

E. Brand, H. Bressers \& J. Lgteringen, "Case Studies on Negotiated Environmental Agrecments" (Paper presented to the NEAPOL, November/December 2000) at 4. Glasbergen, supra note 37 at 133-36.

Supra note 38. See Sanford E. Gaines \& Clionn Kimber, "Redirecting Self-Regulation" (2001) 13 J. Envtl. L. 157 at 166.

54 Part I of the Constitution Act, 1982, being Schedule B to the Canada ACt 1982 (U.K.), 1982, c. II [Charter].

3) Sumikura, supra note 40 at 8.

s. Julich \& Falk, supra note 48 at 15.

s)

Ibid. at 16. 


\section{B. THE LEgal AUTIORITY fOR EMISSIONS TRADING CONFERRED BY THE CONSTITUTION OF CANADA}

In the event that any of the many complexities of multiple and varying Canadian emissions reduction targets and trading systems leads to a legal challenge of a regulated emissions trading system, it is likely that any or all of the trading system's validity, operability and applicability will be challenged under the federal-provincial division of powers as set out in the Constitution. The resolution of such a constitutional challenge will rest first on the determination of the "matter," or the characterization of the emissions trading system in question, and second on the interpretation of the discrete heads of legislative power (which are specific to each of the federal and provincial governments set out in ss. 91 and 92 of the Constitution, respectively) in order to accommodate the matter. ${ }^{58}$

\section{The Characterization of: Proposed Canadian Emissions REDUCIIONS AND TRADING SYSTEMS UNDER THE CONSTITUTION OF CANADA}

To characterize or determine the "matter" of Canadian emissions reductions and trading systems, we have examined the general parameters of the systems set out in the federal Implementation Plan ${ }^{5 y}$ and in Bill $37 .^{60}$ While the purpose of the emissions trading system included in the federal Implementation Plan is to implement the Kyoto Protocol ${ }^{61}$ and, while Bill 37 is intended to reduce GHG emissions independent of the Kyoto Protocol, there are several common features of both emission reduction and trading regimes. Both systems are likely to include:

requirements to reduce air emissions of GHGs and, in Alberta, other criteria air contaminants;

- agreements between industry sectors and government to meet emission reduction targets;

the allocation of government-assured rights to emit GHGs (known as "allowances" or "permits") to regulated entities in accordance with a pre-determined allocation formula;

provision for the creation and use of rights to emit GHGs that may be approved by government (know as emission "offsets") resulting from sequestration of GHGs in forest, agricultural and geological sinks, ${ }^{62}$ and possibly from other GHG emission reduction activities;

- additional requirements for emissions measurement, monitoring and reporting, as well as the verification of stated emission reductions;

a central registry for allowance/permit and offset information and tracking;

(4) Bill 37, supra note 11, as supplemented by Climate Change: Taking Action, supra note 15, and Major Feasibility Study, supra note 18.

Stupra note 1.

$A$ carbon "sink" is generally a component of the enviruniment, such as trees or soil, which removes GHGs from the atmosphere through natural processes. In Alberta's Bill 37, supra note I ], the definition of "sink" in s. I(e) also makes specific provision for sequestration in geological formations. 
- trade in emission allowances/permits and offsets (collectively, "emission products") and related financial instruments, such as current and future options on the right to purchase allowances/permits and/or offsets;

- an annual compliance obligation that requires regulated entities to surrender a quantity of allowances and permits equal to their actual GHG emissions; rules regarding the use and retirement of allowances/permits and offsets; and . penalties for non-compliance.

The intended effects of these emission reduction and trading systems are primarily to stabilize and reduce GHG emissions from sources in Alberta and Canada in an economically efficient manner through the creation and use of a market incentive ${ }^{63}$ As a result, the policy initiatives will also have the effect of creating and regulating a new market(s) in emission products and associated financial instruments.

The proposed emission reductions and trading systems are also likely to impact indirectly the production and trade in certain products by creating new production and operating costs for facilities or industries that are subject to emission reduction requirements and that must purchase emission products to comply with the same. Specifically, the emission reduction and trading systems may affect production of products resulting from, and trade in, goods and services associated with each of the following sectors: thermal power generation; ${ }^{64}$ oil and gas (upstream extraction, oil and gas pipelines and gas utilities petroleum refining); mining; pulp and paper; chemicals (including fertilizers); iron and steel; smelting and refining; cement and lime; and glass and glass container production. In fact, critics have argued that the effect of the proposed federal emissions reductions and trading system is essentially a carbon tax on these products. ${ }^{65}$

The relative impact of the required $\mathrm{GHG}$ emission reductions on each of these industrial sectors is likely to be reflective of the proportion of Canada's GHG profile that each represents, as illustrated in Figure $1 .^{66}$ It is therefore noteworthy that electricity production, fossil fuel (extraction, transport and refining), agriculture and mining represent greater than 50 percent of Canadian GHG emissions. In addition, the emission reduction and trading systems will impact trading in the secondary and financial markets associated with such products, as well as the market in emissions trading services and products. ${ }^{67}$

Emissions trading generally achieves efficient, lower cost emission reductions by allowing multiple emission sources with variable costs of emission reductions to trade in order to achieve a system-wide emission reduction target.

From coal, oil and gas fuel sources.

Statements made by the participants of the National Stakeholders Workshops on Climate Change, Toronto, June 2002.

Janet Peace \& Leah Lawrence. "Greenhouse Gas Constraints Closer Than Think" (Powerpoint presentation to Canadian Heavy Oil Association, September 2002) at 21, online: Climate Change Central <www.climatechangecentral.com/news_room/Greenhouse_Gas_Constraints.pdß, complied from data in Environment Canada, Canada's Greenhouse Inventory. 1990)-2000(Ottawa: Environment Canada, 2002) at 5, Table S-2.

Supra note 65. 
Figure 1. Canadian GHG Emissions by Major Activity 2000

(726 Mt $\mathrm{CO}_{2} \mathrm{eq}$ )

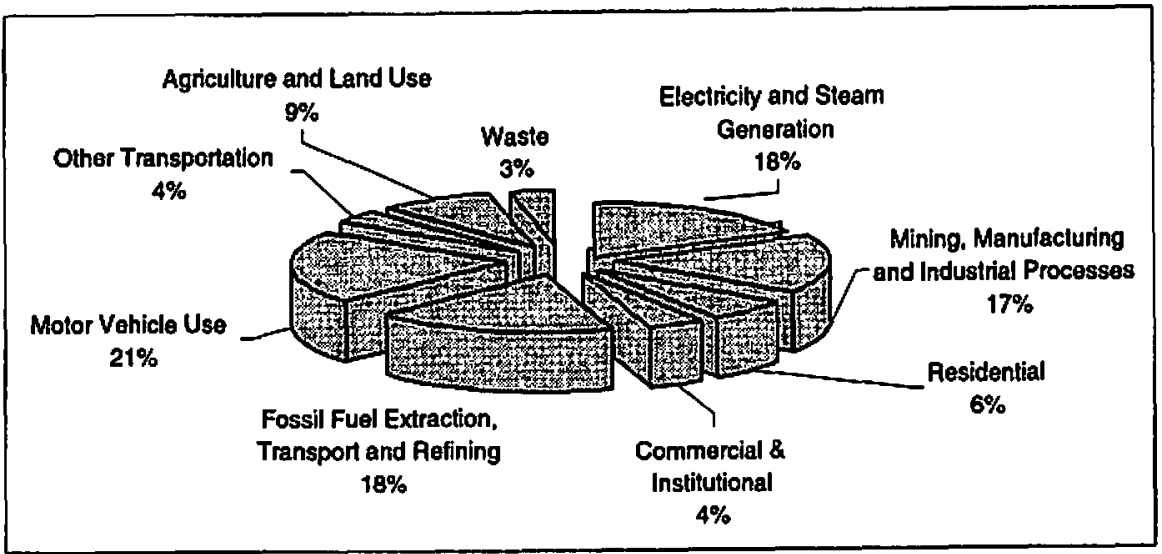

In the event that emission reduction and trading systems are reserved to the provinces and numerous non-contiguous systems are implemented in various provinces, the resulting effect is likely to be fragmented provincial GHG emission markets, which create a barrier to interprovincial and international trade in emission products, associated financial instruments and the above-mentioned industrial products that require emission products as a necessary element of production.

The consideration of the purpose, substance and effect of the proposed GHG emission reduction and trading systems leads to the conclusion that it may be possible to characterize these systems as matters in relation to any of: (i) the implementation of a treaty; (ii) nonrenewable natural resources and forestry in a province; (iii) development, conservation and management of electricity generation sites in a province; (iv) taxation (both generally and in respect of electricity production, non-renewable natural resources, forestry resources); ( $v$ ) environmental protection; and (vi) interprovincial and international trade (or more precisely, a barrier to interprovincial and international trade). The first five of these potential characterizations are considered below. The potential characterization of emissions reductions and trading in the context of interprovincial and international trade has warranted separate consideration given the additional non-constitutional considerations of this third main aspect that are likely to give rise to legal challenge.

\section{i. Implementation of a Treaty}

While it is clear that the federal government has the power to enter into international agreements, ${ }^{68}$ it may not enact implementing legislation that encroaches upon provincial heads of power. ${ }^{69}$ As a result, the federal government may validly ratify the Kyoto Protocol, but may not implement an associated domestic emissions trading system that is in an area of 
provincial competency, such as in relation to property and civil rights (s. 92(13)) or certain natural resources (s. 92A). ${ }^{70}$

The Supreme Court of Canada has validated treaty-implementing legislation that the federal government has enacted where such legislation is in relation to a matter reserved for the federal government under s. 91 of the Constitution." However, in the Labour Conventions Case, Lord Atkin, writing for the Privy Council, found that the federal government's jurisdiction to legislate for the purpose of implementing a treaty obligation does not, in fact, provide it with the authority to enact legislation that is in relation to a matter of provincial jurisdiction under s. 92.

Lord Atkin specifically indicated that if such a broad interpretation of the federal treaty power was taken, "[s]uch a result would appear to undermine the constitutional safeguards of provincial constitutional autonomy."72 Moreover, he expressly indicated that in the event that Canada incurs treaty obligations that deal with provincial classes of subjects, those obligations must be "dealt with by the totality of powers, in other words by co-operation between the Dominion and the Provinces."7]

Given that the implementation of a domestic emissions trading system is not, prima facie, limited to federal competency and will undoubtedly deal with provincial classes of subjects including natural resources and property and civil rights, it is unlikely that the federal government has the legislative authority to implement such a system on the sole basis of its powers to enter into and implement treaties.

\section{ii. Non-Renewable Natural Resources and Forestry in a Province}

Section 92A of the Constitution provides each province with the power to make laws in relation to the exploration for non-renewable natural resources in the province (s. 92A(I)(a)) and the development, conservation and management of non-renewable natural resources and forestry resources in the province, including laws in relation to the rate of primary production therefrom (s. 92A(1)(b)). ${ }^{74}$ In the event that the proposed emission offset mechanism pertains directly to provincial forestry resources or the emission reduction targets affect the development or rate of production of other non-renewable natural resources in a province, all or part of the federal emission reductions and trading system may be found to be ultra vires the federal government. While these aspects may be central to the proposed offset mechanism that forms part of the proposed federal emissions reductions and trading system, it is unlikely that forestry or natural resources will be determined to be the pith and substance of the entire emissions trading regime.

70 Constiturion, supra note 36.

"Ihid. See also Mac Donaldv. Vapour Canada Lid. [1977] 2 S.C.R. 134: Francis v. The Queen, [1956]

S.C.R. 618 at 621.

12 Supra note 69 at 682.

1 Ibid. at 684.

34 Supra note 36. 
iii. Development, Conservation and Management of Electricity

Generation Facilities in a Province

Similarly, ss. $92 \mathrm{~A}(1)(\mathrm{c})$ and $92 \mathrm{~A}(2)^{75}$ provide the provinces with the constitutional power over the development, conservation and management of electrical energy generation facilities in the province and the export of electricity. Therefore, in the event that the federal emission reduction targets and trading system (that are likely to target the 18 percent of Canadian GHG emissions that arise from the electricity sector) affect the development or export of electricity in a province, the system may be challenged as beyond the jurisdiction of the federal government.

Again, it is more likely that the comprehensive federal emission reductions and trading system will be construed as merely incidental rather than in relation to electricity facilities and exports. If the matter, however unlikely, is construed as a matter in relation to electricity exports from a province, it is possible that the federal government may be afforded both the jurisdiction to act in this area ${ }^{76}$ and paramountcy, should its initiatives conflict with a provincial system. ${ }^{77}$

\section{iv. Taxation}

If the emission reductions and trading system is construed as a tax on the production of carbon-intense products (such as oil, gas, electricity, steel, metals, chemicals, cement, forest products and glass), the federal government is afforded broad power under s. 91(3) of the Constitution to impose such a tax either directly or indirectly. ${ }^{78}$ The provincial taxation powers are limited to direct taxes within the province to raise revenue for provincial purposes pursuant to s. 92(2) of the Constitution, and indirect and direct taxes in relation to natural resources in the province pursuant to $92 \mathrm{~A}(4)$ of the Constitution. ${ }^{79}$

Given that the federal government considered and rejected an upstream carbon tax on energy production and chose instead to implement direct emission constraints on large final emitters, it is unlikely that the courts would characterize the emission reductions and trading system as a tax.

It is the authors' opinion that the two most likely characterizations for GHG emissions reductions and trading systems are in relation to environmental protection and interprovincial and/or international trade.

\section{v. Environmental Protection}

One of the central and dominant features of the proposed emission reductions and trading system is, in fact, the intended reduction of GHG emissions to the atmosphere from stipulated large industrial emitters. As a result, a dominant feature of the system appears to be to protect

lbid. , s. 9 l(2) (international trade and commerce).

lbid., s. 92A(3).

Winterhaven Stables v. Canada (1988), 53 D.L.R. (4th) 413 (Alta. C.A.).

Supra note 36. 
the environment and address global climate change through the control of GHG emissions to the atmosphere.

However, there is no discrete class of subject in the Constitution that allocates jurisdiction over the environment to either the provinces or the federal government. The Supreme Court of Canada has both confirmed that the environment is a "constitutionally abstruse matter which does not comfortably fit within the existing division of powers without considerable overlap and uncertainty",;0 and that it is a matter of shared, ${ }^{81}$ concurrent, or overlapping ${ }^{82}$ jurisdiction between the provinces and federal government. As a result, valid federal or provincial environmental legislation must be respectively linked to an appropriate s. 91 or s. 92 head of power. ${ }^{83}$

\section{a. Environmental Protection and Peace, Order and Good Government}

Federal environmental legislation, purportedly implementing a marine pollution treaty ${ }^{84}$ and affecting discharges of pollution into marine waters located within a province, has been justified under the federal government's authority to enact laws for the "Peace, Order, and good Government" (POGG) of Canada, as set out in the opening paragraph of s. 91 of the Constitution. ${ }^{35}$ In Crown Zellerbach, ${ }^{86}$ the Supreme Court of Canada found that the impugned federal environmental legislation was within the jurisdiction of the federal government on the grounds that:

marine pollution, because of its predominantly extra-provincial as well as international character and implications, is a matter of national concern to Canada as a whole; ${ }^{87}$

although marine pollution in provincial waters is not a new matter for Canada and originally constitutes a matter of a local or private nature in a province, it has become a matter of national concern; ${ }^{88}$

the lack of a clear visual boundary between the territorial sea and the internal marine waters of the province supports the indivisibility of the matter; ${ }^{89}$

the pollution of marine waters (either within or outside the provinces) is distinct from the pollution of fresh waters, and therefore is a single, indivisible matter; ${ }^{\infty 0}$

Friends of the Oldman River Society v. Canada (Minister of Transport \& Minister of Fisheries and Oceans). [1992] I S.C.R. 3 at 64 [Friends of the Oldman River].

Jbid. at 62-65.

R. v. Crown Zellerbach Lid., [1988] I S.C.R. 401 at 433 [Crown Zellerbach].

Friends of the Oldman River, supra note 80 at 68.

Comention on the Prevention of Marine Pollution by Dumping of Wastes and other Matter, 29 December 1972. Can. T.S. 1979. No. 36 (entered into force 30 August 1975, accession by Canada 13 December 1975).

Crown Zellerbach, supra nole 82; Constitusion, supra note 36.

Crown Zellerbach. ibid. at $431 \cdot 38$.

Ibid. at 436.

However, it is noteworthy that La Forest J., writing for the minority of the Court, found that the power to regulate marine pollution unacceptably encroached upon areas of provincial jurisdiction, including industrial and municipal activity, resource development, construction and recreation (ibid. at 458).

Jbid. at 437.

Ibid. at 436. 
the marine water/fresh water distinction in the impugned legislation constitutes a reasonable and ascertainable limit on the impact of the federal legislation on provincial jurisdiction;

- the effect on extra-provincial interests if the federal government failed to deal effectively with the intra-provincial aspects of marine pollution in provincial waters (the "provincial inability" test) is relevant for determining whether the matter is sufficiently single and indivisible to make it a matter of national concern; and "[i]t is because of the interrelatedness of the intra-provincial and extra-provincial aspects of the matter that it requires single or a uniform legislative treatment."11

It appears that a prima facie case may be made out that GHG emissions reduction and trading is a matter of national concern to Canada, given that: (i) the new and international dimensions of the Kyoto Protocol; (ii) the extra-provincial and unbounded nature of the flow of air, and associated air pollution; (iii) international actions to address global warming; (iv) the underlying global atmospheric chemistry of the effects of GHG emissions; and (v) the inter-relatedness of the intra-provincial and extra-provincial aspects of GHG emission trading systems to limit such emissions.

In particular, federal emissions trading legislation is likely to be supported by the provincial inability test. It is unlikely that any province would have the ability to limit the transboundary transport and global effects of GHG emissions. Moreover, it is questionable whether the purpose of reducing GHG emissions from industrial emitters across Canada at the lowest compliance costs will be fulfilled if multiple and fragmented emission markets arise through provincial implementation.

Even if GHG emissions reductions and trading is found to be a matter of national concern, it is noteworthy that federal legislation implementing an emissions trading system including matters that are clearly within provincial control (such as forestry and natural resource based emission offsets) may still be read down.

The decision in Crown Zellerbach supports the position that there is co-ordinate federal and provincial jurisdiction over the proposed GHG emissions reductions and trading system. Quoting Professor Gibson and relying on Professor Hogg, Dickson C.J.C. found that:

It is important to emphasize however that the entire problem would not fall within federal competence in such circumstances. Only that aspect of the problem that is beyond provincial control would do so. Since the "P.O. \& G.G." clause bestows only residual powers, the existence of a national dimension justifies no more legislation than is necessary to fill the gap in provincial powers.;

The "provincial inability" test must not, however, go so far as to provide a rationale for the general notion, hitherto rejected in the cases, that there must be a plenary jurisdiction in one order of government or the other to deal with any legislative problem; ${ }^{93}$ 
and

Where it would be possible to deal fully with the problem by co-operative action of two or more legislatures, the "national dimension" concerns only the risk of non-co-operation, and justifies only federal legislation addressed to that risk."

Consequently, it is very likely that the law as stated in Crown Zellerbach would support federal legislation enacting a system of consistent national emission reduction requirements and over-reaching emission trading rules, but not offset creation rules that are directed at creating emission reduction commodities from provincially-controlled forestry, renewable electricity generation and other natural resources.

In the unlikely event that federal jurisdiction over GHG emissions reductions and trading is characterized as being of national concern and the federal government is afforded exclusive jurisdiction over it, ${ }^{95}$ conflicting or detracting provincial emissions trading programs may be ultra vires the provinces. However, such an interpretation is unlikely, given the Court's ruling in R. v. Hydro-Québec. ${ }^{96}$

\section{b. Environmental Protection and Criminal Law}

In Hydro-Québec, the Supreme Court limited both the scope and the use of the national concern test in relation to federal environmental legislation. Finding that federal toxic substances legislation was upheld as being in relation to the federal criminal law power, the Court did not use the doctrine of national concern, despite express statutory wording to that effect. ${ }^{97}$ Instead, the Court relied on the existence of a prohibition and penalty to uphold the federal legislation as in relation to the criminal law. ${ }^{93}$

It is particularly noteworthy that: (i) La Forest J., writing for the majority, again confirmed that the Constitution affords concurrent jurisdiction over the environment to both levels of government; ${ }^{99}$ and (ii) Lamer C.J.C., writing for a four judge minority, would not have upheld the impugned federal environmental legislation on the basis of either national concern or criminal law. The minority would have struck down the legislation on the grounds that it may "encroach widely upon several provincial heads of power."100

Given that the federal government intends to implement the GHG emission reduction and trading obligations through sectoral covenants with certain industries, it is unlikely that the system could be supported by the "prohibition and penalty" reasoning and criminal law power applied by the Court in Hydro Québec. ${ }^{101}$ It is more likely that the emissions trading

Ibid. al 433.

In the authors opinion this grant of exclusive jurisdiction would be beyond that contemplated and afforded in Crown Zellerbach, ibid, at 434.

[1977] 3 S.C.R. 213 [Hydro-Québec].

Cancdian Environmental Protection Act, R.S.C. 1985, c. 16 (4th Supp.), Preamble [CEPA].

Hydro-Québec, supra nole 96.

Ibid: ; see also Friends of the Oldman River, supra note 80 at 62.65 .

Hydro-Québec, supra note 96 at 250-56, 263.

Joseph F. Castrilli, Legal Authority for Emissions Trading in Canada (Ottawa: National Round Table on the Environment and the Economy, 1999) at 11. 
system would fall outside of the criminal law-based environmental jurisdiction afforded to the federal government in Hydro Québec, despite the fact that the proposed covenants with industry will be supported by a "regulatory or financial backstop" and an associated administrative law structure. As a result, the most likely basis for upholding environmental legislation implementing a federal emissions trading system would be as a matter of national concern.

\section{c. Environmental Protection, Provincial Powers and Territorial Competence}

A provincial emissions trading system may be upheld on the basis of a number of provincial heads of power, including: public lands, including timber and wood thereon (s. 92(5)); municipal institutions (s. 92(8)); local works and undertakings (s. 92(10)); property and civil rights in the province (s. 92(13)); matters of a local or private nature (s. 92(16)); and natural resources (s. 92A)) ${ }^{102}$ However, to the extent that the federal government also implements an emission trading system (as it intends to do), it is possible that a federal emissions trading system that encroaches upon aspects of a provincial emissions trading system (such as certain property and civil rights) may be justified as merely incidental to the pith and substance of controlling transboundary GHG emissions or may be read down to limit the encroachment.

In Interprovincial Co-Operatives $v$. The Queen, ${ }^{103}$ the Supreme Court found that it was beyond the legislative competence of the Province of Manitoba to regulate pollution outside the boundaries of the province, regardless of the effect within the province. This ruling confirmed that the federal government has the authority to control pollution that crossed provincial boundaries and resulted in the reading down of the Manitoba legislation to limit its effect. ${ }^{104}$ Given the transboundary nature and transport of GHG emissions, a provincial emissions trading system that attempts to regulate same may be similarly limited in its application.

\section{d. Conclusion on the Environment}

Certainly from the authors' perspective there does not appear to be an unassailable class of subject or source of environmental jurisdiction that the federal government could rely upon to regulate and implement a GHG emissions reduction and trading system without inevitably encroaching upon provincial areas of competence.

\section{Legal Challenges Related to interprovincial AND INTERNATIONAL TRADE}

In addition to environmental protection, another of the central and dominant features of the proposed emission reductions and trading systems is the creation and regulation of trade in new emissions products and related financial instruments. As a result, a competing (and possibly equally important) feature of the systems appears to be the regulation of trade and 
commerce in emission products and emission markets. While there is no discrete class of subject pertaining to emissions trading per se, it would likely fall within the federal and provincial classes of subjects pertaining to trade and commerce. Specifically, s. 91(2) confers jurisdiction over interprovincial trade and commerce on the federal government, while the provincial jurisdiction over property and civil rights in s. 92(13) has been held to provide the provinces with jurisdiction over intra-provincial trade. ${ }^{103}$ However, Supreme Court jurisprudence indicates that the dividing line between the spheres of provincial and federal trade competence is far from clear. Consequently, the jurisprudence provides only limited direction on the question of how any trade and commerce jurisdiction over emissions trading may be divided between the federal and provincial governments.

The Privy Council first considered issues regarding the shared federal and provincial jurisdiction over trade and commerce in Parsons. ${ }^{106}$ The Court found that, in considering the constitutional validity of Ontario insurance legislation, the federal trade and commerce powers provided by s. 9l(2) of the Constitution are not unlimited. Specifically, the Court found that although Parliament has the power to regulate interprovincial trade and general trade affecting the whole Dominion, the federal trade jurisdiction does not extend to the regulation of contracts of a particular business or trade in a single province. ${ }^{107}$ Such matters fall within provincial jurisdiction over property and civil rights under s. 92(13) of the Constitution ${ }^{108} \mathrm{As}$ a result, a federal emissions trading system that regulates emissions trading contracts or ownership provisions therein may be subject to jurisdictional challenge.

Similarly, challenged provincial legislation regulating the use of, and commodity prices for, coal and gas within the Province of British Columbia was upheld by the Supreme Court of Canada. ${ }^{109}$ Despite strong arguments that the industry was integrated and of an interprovincial and international nature, the Court found that the provincial legislation was valid under provincial trade jurisdiction, as the pith and substance of the legislation was to regulate a particular business entirely within the Province. ${ }^{110}$ Therefore, it is possible that provincial emissions trading systems that are limited to the territory of the province and address only one industry, such as energy, may be validly within provincial trade power. The environmental effectiveness and economic efficiency of such a system would, however, be very limited by its size and scope.

In the same vein, federal legislation aimed at regulating production and labelling in only the beer industry was found to be invalid under s. 91(2) of the Constitusion." In Labatt Brewing v. Canada, Estey J., writing for the majority of the Supreme Court, rejected the general branch of the federal trade power set out in Parsons and found that:

even if this statute were to cover a substantial portion of Canadian economic activity, one industry or trade at a time, by a varying array of regulations or trade codes applicable to each individual sector. there would not.

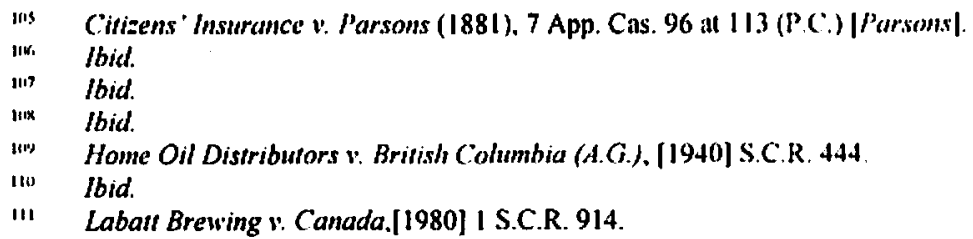


in the result, be at law a regulation of trade and commerce in the sweeping general sense contemplated in the Citizens Insurance case [Parsons], supra. That, in my view, is the heart and core of the problem confronting the respondent in this appeal. Thus the provisions regulating malt liquors relate either to a single industry or a sector thereof, while other regulations appear to concern themselves in a similar way with other individual industries ... I conclude, therefore, in this part, that the impugned sections as they relate to malt liquors cannot be founded in the trade and commerce head of jurisdiction. ${ }^{12}$

Based on this case, it is possible that certain provinces may challenge the proposed emissions trading system in the event that the system significantly and uniquely affects production in a particular industry located within the province. In addition, the reasoning in this case is particularly problematic for any federal regime that would require disclosure of the emissions and/or environmental benefits associated with various forms of electricity products, such as wind power or coal-fired electricity.

However, the above-mentioned intra-provincial trade powers that are afforded to the provinces are not without limits. Such limits may be gleaned from both the obiter dicla in Interprovincial Co-operatives, and the ruling in Manitoba (Allorney General) v. Manitoba Egg and Poultry Assn. ${ }^{113}$ In the latter case, the Court found a provincial egg marketing and quota plan to be outside the jurisdiction of the province as it was aimed primarily at effecting extra-provincial production restrictions. Justice Pigeon contemplated both the limits on the provincial trade power and its application to the environment as obiter in his decision in Interprovincial Co-operatives. In finding that the pollution was truly interprovincial and the proper subject of federal jurisdiction, Pigeon J. indicated that:

the power to regulate by legislation the contracts of a particular business or trade is wilhin the scope of provincial legislative authorily over property and civil rights. However, where business contracts affect interprovincial trade, it is no longer a question within provincial jurisdiction. The matler becomes one of federal jurisdiction.... In my opinion, the same view ought to be taken in respect of pollution of interprovincial waters as with respect to interprovincial trade. ${ }^{1 / 4}$

Clearly, such reasoning could be applied to the international and interprovincial nature of GHG emissions trading and used to support a federal system or restrict or possibly invalidate a provincial emissions trading system, particularly if it allowed for the use of international emission credits.

In Reference re: Agricultural Products Marketing Acl, 1970 (Canada), ${ }^{115}$ the Court was supportive of a complimentary approach to the division of federal and provincial trade powers and validated nearly all of a coordinated federal and provincial egg marketing plan that established quotas for export, intra-provincial and extra-provincial trade. The only invalidated portion of the federal legislation was a section that provided for a provincial marketing board to collect and redistribute levies within the province. Further, the Court supported the provincial legislation that had the effect of controlling production of the

II: $\quad$ Ibid. at 944.

I11 [1971] S.C.R. 689

11. Interprovincial Co-Operatives, supra note 103

Iis [1978] 2 S.C.R. 1198. 
product, finding that the levies were perfectly legitimate to effect federal-provincial cooperative action in regulating a commodity in both intra-provincial and interprovincial trade. ${ }^{116}$

Castrilli applies this case in support of a federal emissions trading regime, particularly one that provides for provincial emission limits and the commoditization of emissions reduction credits. ${ }^{117}$ It is our view that this case provides the best support for a principled and effective emissions trading system that involves both the federal and provincial governments within their respective extra-provincial and intra-provincial spheres of trade competence. However, it is possible that judicial force of this ruling may be limited, given that Professor Hogg opines that "the case is an unusual one and may not be an important precedent."18

Most recently, the Supreme Court set out a series of indicia that would support the validity of federal legislation under the federal government's general trade and commerce power and applied a related test for determining the validity of federal legislation under the trade and commerce power. ${ }^{119}$ In General Motors of Canada Lid. v. City National Leasing Ltd., Dickson C.J.C. upheld federal combines legislation and set out the following five nonexhaustive indicia of valid legislation under the general branch of the federal government's trade and commerce power:

First, the impugned legislation must be part of a general regulatory scheme. Second, the scheme must be monitored by the continuing oversight of a regulatory agency. Third, the legislation must be concerned with trade as a whole rather than with a particular industry.

(i) the legislation should be of a nature that the provinces jointly or severally would be constitutionally incapable of enacting; and (ii) the failure to include one or more provinces or localities in a legislative scheme would jeopardise the successful operation of the scheme in other parts of the country. ${ }^{120}$

In applying this case to emissions trading legislation, Castrilli suggests that all five indicia would support federal action. ${ }^{121}$ In forming this opinion, the authors believe that Castrilli was both optimistic and without the benefit of any of the details of the proposed federal emissions trading system. First, while the emissions trading system is likely to be part of a regulatory scheme, it is a market-based regulatory tool that is designed to minimize administrative burden and harness market forces to effect regulatory goals. As a result, the nature and extent of regulatory agency oversight of the emissions trading system is less than certain. Second, the proposed emissions trading system is not concerned with trade as a whole, but is rather targeted at nine carbon-intense industrial sectors. Third, the experience of several U.S. states would indicate that there is a related constitutional precedent to support provincial emissions trading, although the authors acknowledge that such patchwork trading systems are far less effective and efficient than a coordinated system. Finally, the GHG emissions profile of Canada would indicate that the vast majority of Canadian GHG emissions are produced in

\footnotetext{
IIi. Ibid.

117 Castrilli, supra note 101 at 15.

11* Hogg, supra note 20 at $535-36$

119 [1989] I S.C.R. 641.

180 Ibid. at 661 .

131 Supra note 101 at 17.
} 
a small number of provinces. As a result, although the failure to include one or more of the low-emitting provinces may create politically undesirable impacts, it may not necessarily jeopardize the successful operation of the emissions trading scheme in other parts of the country.

In summary, the jurisprudence set out above clearly indicates that there is an amount of judicial tolerance for overlap between federal and provincial enumerated heads of power relating to trade and commerce that may give rise to valid provincial authority to regulate certain aspects of emissions reductions and trading in the province. To the extent that such provincial emissions trading systems may have the effect of creating a barrier to interprovincial trade in emission products and related financial instruments by fragmenting what would otherwise be a national emissions market, it will be necessary to determine what relevant Constitutional doctrine is to be applied in the event that a valid provincial emissions trading system creates a barrier to interprovincial trade in emission products and related financial instruments.

Professor Hogg advocates that, in such a case, the weight of the jurisdictional authority should be balanced in favour of the federal government's authority over general trade and commerce, which must necessarily extend beyond the regulation of interprovincial and international trade in order to be effective. ${ }^{122}$ In the event that a federal emissions trading system has incidental or ancillary effects on matters clearly within a valid provincial emissions trading system, Professor Hogg believes that the legislative authority is concurrent and that the encroachments of the federal emissions trading system would be justified if there is a "rational, functional connection" between the portion of the emissions trading system which is good and that which is challenged. ${ }^{123}$ Although there is a body of Canadian jurisprudence that would support such a view, ${ }^{124}$ we believe that the better view, which is more reflective of the underlying principles of federalism, is expressed by Vegh. ${ }^{125}$

Vegh relies upon the ancillary doctrine to opine that the test for valid encroachment into the general sphere of intra-provincial trade is more onerous. In the case of provincial emissions trading, a serious intrusion into an area of provincial competence (such as electricity facilities) on the basis of interprovincial or international trade would only be justified if it were necessary to implement the federal emissions trading system. ${ }^{126}$

In considering the question of what happens when provincial legislation in relation to a local trade matter has the result of impeding or effectively preventing the interprovincial flow of trade, ${ }^{127}$ Vegh suggests that interprovincial trade barriers should be characterized by reference to the disproportionate impact that the provincial measure has on the flow of trade between provinces. Vegh uses the term "disproportionate impact" specifically to refer to the

\footnotetext{
12. Hogg, supra note 20 at 536.

121 Thid. al $405-406$.

124 Sec Papp v. Papp, [1970] I O.R. 33 ] (C.A.); R. v. Zelensky, [1978] 2 S.C.R. 940; Mulliple Access v. McCurcheon, [1982] 2 S.C.R. I61.

las George Vegh, "The Claracterization of Barriers to Inter-provincial Trade under the Canadian Constitution" (1996) 34 Osgoode Hall L.J. 355.

12, Ibid

$127 \quad$ bid. at 357.
} 
trade impediments that are not necessary to implement the objectives of otherwise valid legislation as identified through the ancillary (or necessarily incidental) doctrine of constitutional interpretation. ${ }^{123}$

In the case of federal and provincial emissions reductions and trading systems, the Vegh test may therefore support coordinated federal and provincial emissions trading systems, but may not allow for the encroachment of the federal system into areas of provincial competence, such as the creation of emission offsets from forestry and non-renewable natural resources in the province.

\section{Trade Challenges beyond the Constitution}

The constitutional analysis in relation to trade and commerce is further complicated when one considers potential challenges that may arise under international trade agreements such as the North American Free Trade Agreement Between the Government of Canada, the Government of Mexico and the Government of the United States. ${ }^{129}$ On 1 May 2003, the Attorneys General of the States of New York, Connecticut and Rhode Island filed a petition against a major Ontario electricity generator under ss. 14 and 15 of the North American Agreement on Environmental Cooperation (generally referred to as the environmental side agreement to the NAFTA) ${ }^{130}$ The petition asks the NAFTA Commission for Environmental Cooperation to investigate the Federal Government's failure to control transboundary air emissions from two Ontario-based coal-fired power plants located on the southern portion of the Ontario border with several U.S. states.

Even under the Vegh test, the impacts of related international trade challenges of this nature may lead to the determination that federal emission reduction and trading measures that would otherwise be viewed as having serious and disproportionate impacts on provincial emissions trading are necessary to implement an effective federal emissions reduction and trading regime and to limit barriers to international trade.

In conclusion on this point, although the federal jurisdiction over general trade and commerce may be increasingly used to limit the scope of provincial emissions trading initiatives, there continues to be uncertainty in the scope of federal and provincial trade powers. In addition to mounting international trade concerns regarding transboundary air emissions, this uncertainty emphasizes the need for coordination and harmonization between governments in their development and implementation of $\mathrm{GHG}$ emission reduction and trading policy initiatives.

Such co-ordination may be modelled on the actions and result of the Federal-Provincial Working Group (FPWG) on Controls Harmonization (now the FPWG on Ozone-depleting Substances and Halocarbon Alternatives) that provides for a comprehensive federalprovincial mechanism to implement the Montreal Protocol on Substances that Deplete the

17 December 1992, Can. T.S. 1994, No. 2, 32 I.L.M. 289 (entered into force I January 1994) [NAFTA]. As described in the press release of New York Attorney General Elliot Spitzer, online: Oflice of the New York Stale Attorney General <www.oag. state.ny.us/press/2003/may/may0la_03.himl>. 
Ozone Layer. ${ }^{131}$ As a result of this initiative, the two levels of government have agreed upon discrete but interacting spheres of competence, such that the federal government addresses both the production and trade of ozone-depleting substances (ODS) under the $C E P A^{132}$ and provincial govermments address ODS emissions and releases into the environment. ${ }^{133}$ Such a coordinated and harmonized approach is also directed by the Canada-wide Accord on Environmental Harmonization ${ }^{134}$ that was agreed upon by federal, provincial and territorial Ministers of the Environment on 29 January 1998. Finally, the Canadian Agreement on Internal Trade (AIT) would also support true coordination, cooperation and harmonization of the federal and provincial governments in implementing an effective GHG emissions trading system. ${ }^{135}$

\section{Conclusions}

The federal and several provincial governments are now in the process of developing and implementing GHG emission reduction policies and emission trading systems to reduce GHG emissions in Canada and the provinces. A large number of practical challenges to the development of a robust, liquid, integrated and efficient Canadian GHG market may result from the current attempts of provincial and federal governments to implement different and varying emission reduction and trading systems. In fact, many of the base elements of an emissions trading system (such as the emission limits, allocation mechanism and compliance or usage rules) may be at odds if Canadian policy makers continue to develop entirely independent provincial and federal emissions trading policy.

In addition, the use of environmental covenants between industry and government to effect emission reductions and compliance with GHG emissions trading systems may result in several legal challenges, particularly if such covenants are not supported by legislation and open to public scrutiny. Such issues are compounded if both the provinces and the federal governments enter into emissions trading covenants with the same industrial participants.

Finally, the authors conclude that the shared federal and provincial constitutional jurisdiction over both environmental protection and trade and commerce provides strong support for the implementation of a single, coordinated Canadian GHG emissions trading system that is jointly developed and implemented by the federal and provincial governments. This may be best achieved by ensuring that provincial governments retain and exercise their jurisdiction in relation to environmental protection and intra-provincial trade through express

Canadian Ozone Layer Protection Program Strategy and Recommendations for a Consistent Federal Provincial Regulatory Approach, September 1990, online: Environment Canada < www.ec.gc.ca/ozone/ doc/UO/Primer/EN/index.cfm?p=54>. Supra note 97.

For example, the Ozone-Depleting Substances Regulation (Alta. Reg. 125/93) in Alberta, the Ozone Depleting Substances Regulation (B.C. Reg. 53/93) in British Columbia, the Ozone Depleting Substances-General Regulation (R.R.O. 1990, Reg. 356) in Ontario, and the Ozone Layer Protection Regulations (N.S. Reg. S4/95) in Nova Scotia. Harmonization (Oltawa: CCME, 1998).

is) A Consolidation of the Agreement on Internal Trade (updated August 2002), online: Industry Canada, Strategis <strategis. ic.gc.ca/epic/inait-aci.nsf/vwapj/agreement2002.pdf/SFile/agreement2002.pd\$ . The AIT has been amended by four protocols between November 1995 and February 2001. 
authority over the creation of offsets in their territory, as part of a larger, provincially coordinated offset mechanism. The resulting comprehensive GHG emissions market therefore would be administered by both levels of government in a manner that is both reflective of the distribution of powers conferred by the Constitution and enshrined in the underlying principles of federalism. 


\begin{tabular}{|c|c|c|}
\hline Implementing Legislation & Section Number & Provisions \\
\hline $\begin{array}{l}\text { Canada - Canadian } \\
\text { Environmental Protection Act, I } \\
\text { S.C. } 1999, \text { c. } 33\end{array}$ & $\begin{array}{l}\text { ss. } 162,322,326 \text {, } \\
327\end{array}$ & $\begin{array}{l}\text { 162. (1) Regulations that prescribe standards in relation to emissions may provide for a system of credits } \\
\text { based on the following principles: } \\
\text { (a) a company may establish that vehicles, engines or equipment conform to those standards by applying } \\
\text { credits against emissions of the vehicles, engines or equipment in the prescribed manner and within } \\
\text { prescribed limits; } \\
\text { (b) credits may be obtained by a company in the prescribed manner } \\
\text { (i) by reference to emissions of the vehicles, engines or equipment that more than meet the requirements of } \\
\text { those standards, or } \\
\text { (ii) by the payment of an amount to the Receiver General determined at a prescribed rate in relation to } \\
\text { emissions of the vehicle, engine or equipment; and } \\
\text { (c) credits obtained by reference to emissions may be transferred to or from a company in the prescribed } \\
\text { manner. } \\
322 . \text { The Minister may establish guidelines, programs and other measures for the development and use of } \\
\text { economic instruments and market-based approaches to further the purposes of this Act, respecting systems } \\
\text { relating to } \\
\text { (a) deposits and refunds; and } \\
\text { (b) tradeable units. } \\
326 \text {. The Governor in Council may, in the exercise of a regulation-making power under section } 93,118 \text {, } \\
\text { 140, } 167,177 \text { or } 209 \text {, make regulations respecting systems relating to tradeable units, including regulations } \\
\text { providing for, or imposing requirements respecting. } \\
\text { (a) the substance, product containing a substance or quantity or concentration of the substance that is } \\
\text { released or activity in relation to which the system is established; }\end{array}$ \\
\hline
\end{tabular}




\begin{tabular}{|c|c|c|}
\hline Implementing Legislation & Section Number & Provisions \\
\hline $\begin{array}{l}\text { Canada - Canadian } \\
\text { Environmental Profection ACt, } 1 \\
\text { S.C. } 1999, \text { c. } 33\end{array}$ & $\begin{array}{l}\text { ss. } 162,322,326 \text {, } \\
327\end{array}$ & $\begin{array}{l}\text { (b) the methods and procedures for conducting sampling, analyses, tests, measurements or monitoring under } \\
\text { the system; } \\
\text { (c) the description and nature of a tradeable unit, including allowances, credits or coupons; } \\
\text { (d) the baselines to be used for comparison or control purposes in relation to the system and the maximum } \\
\text { limits applicable to the system and the manner of determining those baselines and maximum limits; } \\
\text { (e) the conditions related to the creation, distribution, exchange, sale, use, variation or cancellation of a } \\
\text { tradeable unit; } \\
\text { (f) the creation, operation and management of a public registry related to the system; } \\
\text { (g) the conditions for the use of and participation in the system, including environmental or temporal limits; } \\
\text { (h) repons and forms related to the system; and } \\
\text { (i) the maintenance of books and records for the administration of any regulation made under this section. } \\
\text { 327. Despite any regulation made under section } 326 \text {, the Minister may issue an order setting conditions in } \\
\text { respect of the trading or suspend or cancel trading of tradeable units or invalidate any trade of tradeable } \\
\text { units where the Ministers are of the opinion that the trade or usc of a tradeable unit } \\
\text { (a) has or may have an immediate or long-term harmful effect on the environment; } \\
\text { (b) constitutes or may constitute a danger to the environment on which human life depends; or } \\
\text { (c) constitutes or may constitute a danger in Canada to human life or health. }\end{array}$ \\
\hline $\begin{array}{l}\text { Ontario-Environmental } \\
\text { Protection Act, R.S.O. 1990, c. } \\
\text { E-19, as am. by S.O. 1998, c. 15, } \\
\text { Sched. E, s. } 10\end{array}$ & s. 176.1 & $\begin{array}{l}\text { 176.1 The Lieutenant Govemor in Council may make regulations, } \\
\text { (a) establishing programs and other measures for the use of economic and financial instruments and market- } \\
\text { based approaches, including without being limited to emissions trading, for the purposes of maintaining or } \\
\text { improving existing environmental standards, protecting the environment and achieving environmental } \\
\text { quality goals in a cost effective manner; and } \\
\text { (b) providing for or designating a body to administer the programs and other measures referred to in clause } \\
\text { (a). }\end{array}$ \\
\hline
\end{tabular}




\begin{tabular}{|c|c|c|}
\hline Implementing Legislation & Section Number & Provisions \\
\hline $\begin{array}{l}\text { Alberta - Environmental } \\
\text { Protection and Enhancement } \\
\text { Act, R.S.A. 2000, c. E-12 }\end{array}$ & s. 13 & $\begin{array}{l}\text { 13. The Minister may, in accordance with the regulations, establish programs and other measures for the use } \\
\text { of economic and financial instruments and market-based approaches, including, without limitation, } \\
\text { (a) emission trading. } \\
\text { (b) incentives, } \\
\text { (c) subsidies, } \\
\text { (d) emission, effluent and waste disposal fees, and } \\
\text { (e) differential levies, } \\
\text { for the purposes of protecting the environment, achieving environmental quality goals in a cost effective } \\
\text { manner and providing methods of financing programs and other measures for environmental purposes. }\end{array}$ \\
\hline $\begin{array}{l}\text { Manitoba - The Environment Acl, } \\
\text { C.C.S.M., c. E125 }\end{array}$ & s. 45 & $\begin{array}{l}\text { 45. The Lieutenant Govemor in Council may, where it is consistent with established environmental quality } \\
\text { objectives, market units of allowable emission of specific pollutants, in accordance with the regulations, and } \\
\text { the revenue so generated may be held in trust by the Minister of Finance as an environmental contingency } \\
\text { fund, to be used at the request of the minister in the event of an environmental emergency. }\end{array}$ \\
\hline $\begin{array}{l}\text { Nova Scotia - Environment Act. } \\
\text { S.N.S. 1994-95, c. I }\end{array}$ & ss. $15(\mathrm{a}), 25(1)(\mathrm{c})$ & $\begin{array}{l}\text { 15. The Minister may, in accordance with the regulations, establish programs for the research, development } \\
\text { and use of economic instruments and market-based approaches for the management of the environment and } \\
\text { for the purpose of achieving environmental quality objectives in a cost-effective manner, including, without } \\
\text { limiting the generality of the foregoing, } \\
\text { (a) tradable emission and efluent permits; } \\
\text { 25.(1) The Govemor in Council may make regulations } \\
\text { (c) regarding research, development and use of economic instruments and market-based approaches; }\end{array}$ \\
\hline
\end{tabular}




\begin{tabular}{|c|c|c|}
\hline Implementing Legislation & Section Number & Provisions \\
\hline $\begin{array}{l}\text { Newfoundland-Environmental } \\
\text { Protection Act, S.N.L. 2002, c. } \\
\text { E-14.2 }\end{array}$ & s. 22 & $\begin{array}{l}\text { 22. The minister may } \\
\text { (li) adopt overall provincial emission caps, production goals and product manufacturing. sale and use } \\
\text { restrictions with respect to air quality issues of regional or global significance; } \\
\text { (.) } \\
\text { (j) establish regional air quality management programs to address the combined effects of multiple sources } \\
\text { of air contaminants; } \\
\text { (k) enter into agreements respecting air quality management issues; }\end{array}$ \\
\hline $\begin{array}{l}\text { New Brunswick - Clean Air Act, } \\
\text { S.N.B. } 1997 \text {, c. C-5.2 }\end{array}$ & s. 46 & $\begin{array}{l}\text { 46. The Licutenant-Governor in Council may make regulations } \\
\text {... } \\
\text { (w) respecting the manufacture, sale or supply, offering to sell or supply or the use of mobile sources of } \\
\text { contaminants and other consumer products that selease or may release a contaminant into the air, including } \\
\text { the establishment and enforcement of objectives. guidelines, standards and requirements in relation to them, } \\
\text { the prohibition of fuels, the establishment of standards for fuels, requirements in relation to pollution control } \\
\text { equipment, the establishment of emission limits and inspection processes and any other matter in relation to } \\
\text { regulating such consumer products; }\end{array}$ \\
\hline $\begin{array}{l}\text { Quebec - Environment Quality } \\
\text { Act.R.S.Q. c. Q-2 }\end{array}$ & s. 31 & $\begin{array}{l}\text { 31. The Govemment may make regulations to: } \\
\text { (.. } \\
\text { (e.l) establish measures providing for the use of economic instruments, including tradeable permits. } \\
\text { enission, effluent and waste-disposal fees or charges, advance elimination fees or charges, and fees or } \\
\text { charges related to the use, management or purification of water, for the purpose of protecting the } \\
\text { environment and achieving environmental quality objectives for all or any part of the territory of Quebec, } \\
\text { and establish any nule necessary or relevant to the functioning of the measures pertaining in particular to the } \\
\text { determination of the persons or municipalities required to pay such fees or charges, the conditions } \\
\text { applicable to their collection and the interest and penalities exigible in case of nonpayment: }\end{array}$ \\
\hline
\end{tabular}




\begin{tabular}{|c|c|c|}
\hline Implementing Legislation & Section Number & Provisions \\
\hline $\begin{array}{l}\text { Yukon - Environment Act, } \\
\text { R.S.Y. } 2002 \text {, c. } 76\end{array}$ & s. 145 & $\begin{array}{l}\text { 145. Despite the Municipal Act and subject to the Public Health Act, the Commissioner in Executive } \\
\text { Council may make regulations relating to Pan } 9 \text { including regulations } \\
\text { (h) prescribing economic regimes or the use of economic tools for encouraging efficiency in air quality } \\
\text { protection, noise control, the use and conservation of water, water quality protection, and the protection, } \\
\text { maintenance and reclamation of land; }\end{array}$ \\
\hline $\begin{array}{l}\text { British Columbia - Bill 57, } \\
\text { Environmental Management Act, } \\
\text { 4th Sess., 37th Parl., British } \\
\text { Columbia. 2003 (assented to } 23 \\
\text { October 2003; Act not in force, } \\
\text { requires regulation) }\end{array}$ & s. 119 & $\begin{array}{l}\text { I19(1) Without limiting section } 138 \text { (1) [general authority to make regulations], the Lieutenant Governor in } \\
\text { Council may make the following regulations: } \\
\text { (a) for the purposes of providing economic incentives to promote environmentally responsible } \\
\text { behaviour, } \\
\text { (i) respecting the variation of fees payable by a person under this Act, including without limitation, } \\
\text { (A) authorizing a director to vary fees, } \\
\text { (B) establishing the criteria the person must satisfy to be eligible for or subject to a variation, } \\
\text { and } \\
\text { (C) limiting the amount of a variation authorized by the director, } \\
\text { (ii) respecting agreements under which the requirements of this Act or the regulations may be } \\
\text { varied, including by adding to, restricting the application of or eliminating requirements, in } \\
\text { relation to that person for the term of the agreement, including without limitation } \\
\text { (A) authorizing the minister to enter into agreements, } \\
\text { (B) establishing the criteria the person must satisfy to be eligible for an agreenent, } \\
\text { (C) speeifying the provisions of the Act or regulations that may be varied under an agreement, } \\
\text { and } \\
\text { (D) requiring public notification to persons affected by an agreement, and } \\
\text { (iii) respecting the establishment of a program of discharge monitoring, registration and trading, including } \\
\text { offsets or credits; }\end{array}$ \\
\hline
\end{tabular}

